\title{
UPAYA PENINGKATAN KETERAMPILAN SOSIAL SISWA MELALUI PERMAINAN TRADISIONAL CONGKLAK
}

\author{
${ }^{1}$ Parji, ${ }^{2}$ Reni Eka Andriani \\ ${ }^{1}$ Program Studi Magister Pendidikan IPS, Program Pascasarjana, IKIP PGRI MADIUN \\ Email:parji.civics@gmail.com
}

\begin{abstract}
Abstrak
Penelitian ini bertujuan untuk meningkatkan keterampilan sosial dengan menggunakan permainan tradisional congklak pada mata pelajaran IPS. Penelitian ini menggunakanpenelitian tindakan kelas dengan dengan 2 siklus. Subyek penelitian ini adalah siswa kelas IV B SDN 03 Nambangan Kidul Kota Madiun yang berjumlah 21 siswa. Teknik pengumpulan data penelitian ini adalah observasi, tes, dan dokumentasi.Hasil penelitian menunjukkan bahwa penggunaan permainan tradisional congklak pada mata pelajaran IPS dapat meningkatkan keterampilan sosial siswa kelas IV B SDN 03 Nambangan Kidul Kota Madiun Tahun Pelajaran 2015/2016. Hal ini ditunjukkan pada siklus I yaitu 7 siswa yang memperoleh kriteria sangat baik dan baik (kriteria penelitian) mencapai 33,3\% dengan rata-rata kriteria cukup. Pada siklus II yaitu 17 siswa yang memperoleh kriteria sangat baik dan baik (kriteria penelitian) mencapai $81 \%$ dengan rata-rata kriteria baik. Selain itu, hasil nilai siswa juga mengalami peningkatan pada siklus I yaitu rata-rata kelas 72,4 dengan kriteria cukup $(66,7 \%)$ dengan jumlah 14 siswa. Pada siklus 2 yaitu rata-rata kelas 82,4 dengan kriteria baik $(85,7 \%)$ dengan jumlah 18 siswa. Hasil nilai siswa pada siklus 1 ke siklus 2 mengalami peningkatan dengan siswa yang sudah tuntas mencapai $\geq 80 \%$ dari jumlah seluruh siswa. Jadi dapat disimpulkan bahwa permainan tradisional congklak pada mata pelajaran IPS dapat meningkatkan keterampilan sosial siswa kelas IV B SDN 03 Nambangan Kidul Kota Madiun.
\end{abstract}

Kata Kunci: Keterampilan Sosial, IPS, Permainan Tradisional Congklak

\section{Improving Students' Social Skills through A Traditional Game of Congklak}

\begin{abstract}
This study aims to improve social skills by using a traditional game, congklak in social science for the sixth grade students of class B, SDN 03 Nambangan Kidul Madiun in the School Year 2015/2016. The study used classroom action research that was conducted in 2 cycles. The subjects of the study was the fourth grade students of class B, SDN 03 Nambangan Kidul Madiun, with a total of 21 students, consisting of 8 female students and 13 male students. Data were collected through observation, test, and documentation. The results shows that using a traditional game, congklak in social science can improve the social skills of the fourth grade students of class B, SDN 03 Nambangan Kidul Madiun in the School Year 2015/2016. It shows from the results that in the first cycle, there are 7 students reaching excellent and good criteria (the criteria suggested) at 33.3\%, with an average of sufficient criterion. In the second cycle, there are 17 students reaching excellent and good criteria (the criteria suggested) at $81 \%$, with the average of good criterion. In addition, the results of students also increase in the first cycle at an average grade of 72.4 belonging to sufficient criterion (66.7\%) with the number of 14 students. In cycle 2, it indicates the increase at the average grade of good criterion, with 82.4 (85.7\%) from 18 students. The results of student scores from cycle 1 to cycle 2 increase with the students' learning accomplishment level at $\geq 80 \%$ of the total number of students. So we can conclude that the traditional game, congklak used in social science can improve the social skills of the fourth grade students of class B, SDN 03 Nambangan Kidul Madiun.
\end{abstract}

Keywords: Social Skills, Social science, Congklak as a traditional game 


\section{Pendahuluan}

Berdasarkan Undang-undang Republik Indonesia Nomer 20 Pasal 3 Tahun 2003 tentang Sistem Pendidikan Nasional bahwa pendidikan nasional berfungsi mengembangkan kemampuan dan membentuk watak serta peradaban bangsa yang bermartabat dalam rangka mencerdaskan kehidupan bangsa, bertujuan untuk berkembangnya potensi peserta didik agar menjadi manusia yang beriman dan bertakwa kepada Tuhan Yang Maha Esa, berakhlak mulia, sehat, berilmu, cakap, kreatif, mandiri, dan menjadi warga negara yang demokratis serta bertanggung jawab.

IPS salah satu disiplin ilmu bertujuan mendidik dan memberi bekal kemampuan dasar kepada siswa untuk mengembangkan diri sesuai dengan bakat, minat, kemampuan dan lingkungannya, serta membahas hubungan antara manusia dengan lingkungannya. Untuk dapat menjalin hubungan yang baik dengan orang lain, dibutuhkan kecakapan yang mampu membuat individu berkomunikasi efektif dengan orang lain. Kecakapan tersebut disebut keterampilan sosial merupakan kecakapan atau kemampuan individu dalam berinteraksi dan berkomunikasi dengan orang lain.

James Banks (1990), mengemukanan pembelajaran Pendidikan Ilmu Pengetahuan Sosial hendaknya dapat mempersiapkan peserta didik agar mereka punya knowledge, skills, attitudes, values dan citizen action.

Secara umum pada pembelajaran IPS guru cenderung menggunakan pembelajaran konvensional dan tanpa bantuan media dalam pembelajarannya. Pembelajaran di kelas hanya berpacu pada buku siswa dengan kegiatan pembelajaran mencatat, menghafal, dan mengerjakan soal. Pembelajaran yang demikian membuat siswa menjadi bosan dan kurang minat dalam belajar.

Sebagaimana dijelaskan oleh Zainal Aqib (2013: 36) bahwa kualitas pembelajaran kita secara umum masih rendah, salah satunya disebabkan profesionalisme guru yang kurang berkembang. Pembelajaran didominasi dengan belajar menghafal kata kata, fakta-fakta atau prosedur-prosedur. Akibatnya, lulusan lemah dalam Bahasa, ketrampilan pemecahan masalah dan tidak mempunyai kreativitas dalam menghadapai masalah sehari-hari uang menantang.

Hal tersebut juga terjadi pada SDN 03 Nambangan Kidul Kota Madiun. Pada pembelajaran IPS khususnya di kelas IV B guru masih cenderung menggunakan pembelajaran konvensional atau ceramah dan berpacu pada buku materi. Mengakibatkan siswa bosan, kurang memperhatikan dan kurang konsentrasi dalam pembelajaran. Serta siswa kurang bekerjasama dengan kelompok. Siswa masih menunjukkan sikap egois, individualis, dan hanya mau berkumpul dengan kelompok pilihannya. Siswa yang paham mengenai materi cenderung acuh pada siswa yang kurang paham. Sehingga kerjasama antar siswa kurang terjalin dan keterampilan sosial siswa kurang berkembang serta berpengaruh pada hasil belajar siswa.

Untuk menciptakan siswa aktif dengan siswa berinteraksi, guru perlu menggunakan variasi model ataupun media dalam mendukung proses pembelajaran. Salah satu cara menciptakan suasana pembelajaran aktif yaitu dengan permainan. Kegiatan permainan berhubungan dengan kegiatan interaksi seseorang dengan orang lainnya dengan adanya aturan.Salah satunya menggunakan permainan tradisional sebagai upaya menciptakan suasana belajar yang variatif dan upaya melestarikan permainan tradisional. Karena anak cenderung memainkan permainan digital dan berlamalama memainkannya sendiri. Hal tersebut mengakibatkan anak individualis tanpa memikirkan lingkungan sekitarnya sehingga terkikisnya sosial anak terhadap lingkungan.

Permainan tradisional yang memungkinkan terjadinya interaksi yang dapat digunakan dalam pembelajaran salah satunya adalah permainan congklak atau dakon. Permainan congklak atau dakon merupakan permainan yang dimainkan oleh 
dua orang atau lebih dengan strategi dan kerjasama kelompok dengan aturan permainan yang harus ditaati. Sehingga memungkinkan siswa berinteraksi dengan saling berkomunikasi, berinteraksi dan menjalin kerjasama dalam kelompok serta menjalin hubungan baik dengan orang lain.

Menurut Widoyoko (2011: 213-214) keterampilan sosial (social skill) diartikan sebagai keterampilan yang dibutuhkan untuk hidup (life skill) dalam masyarakat yang multi kultur, masyarakat demokrasi dan masyarakat global yang penuh persaingan dan tantangan. Keterampilan sosial meliputi keterampilan berkomunikasi, baik secara lisan maupun tertulis dan kecakapan bekerja sama dengan orang lain, baik dalam kelompok kecil maupun kelompok besar.Menurut Goleman (2005: 43) keterampilan sosial merupakan kepintaran dalam menggugah tanggapan yang dikehendaki pada orang lain. Unsur dalam keterampilan sosial meliputi: pengaruh, komunikasi, kepemimpinan, katalisator perubahan, manajemen konflik, pengikat jaringan, kolaborasi dan kooperasi, dan kemampuan tim.

Pendapat yang hamper sama dijelaskan oleh Supriga (2013: 48-56) bahwa diantara program pendidikan IPS adalah dimensi ketrampilan (skills) dan dimensi tindakan (action). Dimensi ketrampilan itu meliputi, ketrampilan mendidik, ketrampilan berfikir, ketrampilan partisipasi social dan ketrampilan berkomunikasi. Sedangkan dimensi tindakan social meliputi percontohan kegiatan dalam memecahkan salah dikelas, berkomunikasi dengan anggota masyarakat, dan pengambilan keputusan.

Sedangkan menurut Thalib (2010: 159) keterampilan sosial meliputi kemampuan berkomunikasi, menjalin hubungan dengan orang lain, menghargai diri sendiri dan orang lain, mendengarkan pendapat atau keluhan dari orang lain, memberi atau menerima umpan balik (feedback), memberi atau menerima kritik, bertindak sesuai norma dan aturan yang berlaku, dan sebagainya.
Dari beberapa pendapat diatas, dapat disimpulkan bahwa aspek-aspek keterampilan sosial dalam penelitian ini yaitu: 1) komunikasi yaitu mengirimkan pesan yang jelas dan meyakinkan, 2) kepemimpinan yaitu membangkitkan inspirasi dan memandu kelompok dan orang lain, 3) pengikat jaringan menumbuhkan hubungan sebagai alat dengan aspek aturan/sportivitas dan ketepatan waktu, 4) kolaborasi dan kooperasi yaitu kerjasama dengan orang lain demi tujuan bersama dengan aspek kerjasama, perhatian, dan berbagi tugas, 5) kemampuan tim yaitu menciptakan sinergi kelompok dalam memperjuangkan tujuan bersama dengan aspek kebersamaan, keaktifan, semangat/ antusias.

Mujib dan Nailur (2011: 34) menyampaikan bahwa permainan yang dimanfaatkan dengan bijaksana dapat menambah variasi, semangat, dan minat pada sebagian program belajar. Santrock (2007: 216) juga menyatakan permainan adalah aktivitas menyenangkan yang dilakukan untuk bersenang-senang dan permainan sosial adalah salah satu jenisnya.Sapriya (2014: 191) bahwa kegiatan partisipasi sosial dapat dilakukan melalui simulasi dan permainan (games) yang merupakan proses pembelajaran atau kegiatan di mana siswa belajar mengenal aturan, berkompetisi, dan sekaligus menjadi pemain yang mungkin pada suatu saat akan menjadi pihak yang menang atau pihak yang kalah.

Mutiah (2010: 147-153) Adapun aspekaspek perkembangan yang dapat dioptimalkan dalam kegiatan bermain, antara lain adalah:

1. Bermain untuk pengembangan kognitif (membantu membangun konsep pengetahuan, mengembangkan kemampuan berpikir abstrak dan kreatif).

2. Bermain untuk pengembangan sosialemosional (membantu mengembangkan kemampuan mengorganisasi dan menyelesaikan masalah, meningkatkan kompetensi sosial meliputi: interaksisosial, kerjasama, menghemat sumber daya, peduli terhadap orang lain, 
seperti memahami dan menerima perbedaan individu, memahami masalah multibudaya, membantu mengekspresikan, membantu menguasai konflik dan trauma sosial, membantu mengenali diri mereka sendiri).

3. Bermain untuk pengembangan motorik (membantu mengontrol gerak motorik kasar dan halus).

4. Bermain untuk pengembangan bahasa/ komunikasi (membantu meningkatkan kemampuan berkomunikasi).

Sadiman (2014:78-81) Sebagai media pendidikan, permainan mempunyai beberapa kelebihan berikut ini:1) Permainan adalah sesuatu yang menyenangkan untuk dilakukan dan sesuatu yang menghibur (kompetisi), 2) Permainan memungkinkan adanya partisipasi aktif dari siswa untuk belajar, 3) Permainan dapat memberikan umpan balik langsung, 4) Permainan memungkinkan penerapan konsepkonsep ataupun peran-peran ke dalam situasi dan peranan yang sebenarnya di masyarakat, 5) Permainan bersifat luwes untuk berbagai tujuan pendidikan dengan mengubah sedikitsedikit alat, aturan maupun persoalannya (permainan dapat dipakai untuk: mempraktikkan keterampilan membaca dan berhitung sederhana, mengajarkan sistem sosial dan sistem ekonomi, membantu siswa atau warga belajar meningkatkan kemampuan komunikatitifnya: memahami pendapat orang lain, memimpin diskusi kelompok yang efektif dan sebagainya, membantu siswa atau warga belajar yang sulit belajar dengan metode tradisional, permainan dapat dengan mudah dubuat dan diperbanyak).

Sedangkan kelemahan dari permainan adalah sebagai berikut: 1) Karena asyik, atau karena belum mengenai aturan/ teknis pelaksanaan, 2) Kebanyakan permainan hanya melibatkan beberapa orang siswa saja padahal keterlibatan seluruh siswa/ warga belajar amatlah penting agar proses belajar bisa lebih efektif dan efisien, 3) membutuhkan kreativitas guru dalam menyiapkan peralatan permainan dan mengkondisikan siswa sesuai dengan tujuan pembelajaran.
Cahyani (2014) bahwa permainan tradisional Indonesia adalah permainan yang berasal dari tradisi dan kebudayaan di setiap daerah di Indonesia. Permainan tradisional Indonesia mengandung nilai-nilai yang sangat berguna dalam kehidupan masyarakat dengan nilai kejujuran, kerja sama, kepemimpinan, dan sportivitas.Menurut Khasanah, dkk (2011) bahwa beragam permainan tradisional mengarahkan anak menjadi kuat secara fisik maupun mental, sosial, dan emosi, tak mudah menyerah, bereksplorasi, bereksperimen, dan menumbuhkan jiwa kepemimpinan.

Salah satu permainan tradisional adalah permainan tradisional congklak. Menurut Fad (2014: 24-25) congklak/ dakon merupakan permainan tradisional yang menggunakan bidang panjang dengan tujuh cekungan pada masing-masing sisi dan dua cekungan yang lebih besar di bagian tengan ujung kiri dan kanan yang disebut sebagai lumbung. Permainan tradisional congklak dimainkan oleh dua orang atau lebih. Cekungan pada sisi diisi dengan biji-bijian (bisa biji sirsak atau biji sawo) atau batu kerikil. Selain itu, ada pula biji congklak yang berasal dari cangkang kerang laut berbentuk bulat agak oval atau tiruannya berbahan plastik berbentuk. Masing-masing cekungan diisi dengan 12 biji. Langkah-langkah permainan tradisional congklak adalah:

1. Lumbung sebelah kanan adalah milik pemain 'A', lumbung sebelah kiri milik pemain ' $\mathrm{B}$ '.

2. Pemain ' $A$ ' memilih salah satu cekungan yang ada pada sisi terdekatnya, mengambil bijinya dan membaginya satu per satu tanpa mengisi lumbung sebelah kanan.

3. Jika biji terakhir jatuh pada cekungan yang ada isinya maka pemain boleh mengambil dan membaginya lagi.

4. Jika biji terakhir jatuh pada bidang kosong, itu berarti pemain ' $A$ ' berhenti bermain dan ganti pemain ' $\mathrm{B}$ ' yang bermain dengan tanpa mengisi lumbung pemain ' $A$ '.

5. Pada permainan congklak, kemenangan dihitung berdasarkan banyak jumlah biji pada lumbung masing-masing pemain. Kunci permainan ini terletak pada pilihan 
jumlah biji pada cekungan yang akan dimainkan. Pemain yang sering berjalan atau mengambil biji dari cekungan maka berarti ia sering mengisi lumbungnya.

Sedangkan permainan tradisional congklak menurut Arie (2015: 35-38) adalah sebagai berikut:

Peralatan bermain:

1. Satu buah papan congklak. Biasanya terbuat dari kayu atau plastik. Ada enam belas buah lubang yang terdiri dari empat belas lubang kecil yang saling berhadapan dan dua buah lubang besar di masingmasing sisinya. Lubang kecil diisi masingmasing tujuh buah biji congklak. Setiap tujuh lubang kecil di sisi pemain dan satu lubang besar di sebelah kanannya adalah milik pemain.

2. Sembilan puluh delapan buah biji congklak, bisa dari cangkang kerang, kerikil, atau biji dari palstik.

Cara bermain:

1. Suit, yang menang mendapatkan giliran pertama untuk bermain.

2. Pemain memilih lubang, mengambil biji congklak didalamnya lalu meletakkan satu demi satu ke lubang di sebelah kanannya sampai habis.

3. Bila biji congklak habis di lubang kecil yang terisi biji milik lawan, maka pemain dapat mengambil biji-biji tersebut lalu melanjutkan mengisi lubang.

4. Jika biji habis tepat di lubang besar miliknya, maka ia dapat melanjutkan permainan dengan memilih lubang kecil miliknya.

5. Bila biji habis di lubang kecil di sisinya, maka ia berhenti, tapi ia dapat mengambil semua biji di lubang milik lawan di depannya.

6. Jika biji terakhir berhenti di lubang di sisi lawan, ia berhenti tanpa mendapatkan apaapa. Kini saatnya giliran ganti pemain.

Permainan selesai jika semua biji ada di lubang besar kedua pemain. Dan pemenangnya adalah yang mendapatkan biji terbanyak. Lubang besar tempat mengumpulkan biji biasanya disebut lumbung.
Menilik beberapa pendapat diatas, dalam penelitian iniada beberapa modifikasi dalam menerapkan permainan tradisional congklak yang telah didesain oleh Aisyah Fad dan Vanda Arie. Hal ini peneliti lakukan berdasarkan tujuan pembelajaran, materi ajar yang akan peneliti sampaikan, serta kondisi siswa di kelas. Dalam hal ini peneliti berdasarkan tujuan dan materi mata pelajaran IPS dengan memperhatikan karakteristik siswa di kelas.

Gunawan (2013:17-18) bahwa hakikat IPS adalah telaah tentang manusia dan dunianya. Manusia sebagai makhluk sosial selalu hidup bersama dengan sesamanya. Rifai (2014) bahwa fungsi IPS sebagai pendidikan adalah membekali anak didik dengan pengetahuan sosial yang berguna, keterampilan sosial yang intelektual, dalam membina perhatian serta kepedulian sosialnya sebagai SDM Indonesia yang bertanggung jawab merealisasikan tujuan nasional. Ilmu sosial adalah suatu bahan kajian yang terpadu yang merupakan penyederhanaan, adaptasi, seleksi, dan modifikasi yang diorganisasikan dari konsepkonsep dan keterampilan sejarah, geografi, sosiologi, antropologi, dan ekonomi (Gunawan, 2013: 48)

Menurut Trianto (2014: 173) ilmu pengetahuan sosial juga membahas hubungan antara manusia dengan lingkungannya. Lingkungan masyarakat dimana anak didik tumbuh dan berkembang sebagai bagian dari masyarakat, dihadapkan pada berbagai permasalahan yang ada dan terjadi di lingkungan sekitarnya.

Dari beberapa pengertian tersebut, dapat disimpulkan bahwa llmu Pengetahuan Sosial (IPS) merupakan suatu ilmu yang mempelajari sosial manusia dengan lingkungannya yang mengkaji masalah hubungan antar manusia untuk mengembangkan tanggung jawab warga negara yang demokrasi.

Menurut Gunawan (2013: 48-49) pembelajaran IPS bertujuan membentuk warga negara yang berkemampuan sosial dan yakin akan kehidupannya sendiri di tengah- 
tengah kekuatan fisik dan sosial, yang pada gilirannya akan menjadi warga negara yang baik dan bertanggung jawab, sedangkan ilmu sosial bertujuan menciptakan tenaga ahli dalam bidang ilmu sosial. Alma (2010: 6) tujuan utama IPS untuk mengembangkan potensi peserta didik agar peka terhadap masalah sosial yang terjadi di masyarakat, memiliki sikap mental positif terhadap perbaikan segala ketimpangan yang terjadi dan terampil mengatasi setiap masalah yang terjadi sehari-hari baik yang menimpa dirinya maupun yang menimpa masyarakat.

Mata pelajaran IPS adalah mata pelajaran yang diberikan kepada peserta didik bertujuan untuk membekali peserta didik dalam kehidupan sosial dan peka terhadap masalah sosial dengan membekali peserta didik akan pengetahuan sosial yang berguna, keterampilan sosial dan intelektual dalam membina perhatian serta kepedulian sosialnya sebagai SDM yang bertanggung jawab.

Berdasarkan uraian di atas menarik untuk diteliti terutama bagaimanakah penggunakaan permainan tradisional congklak dalam meningkatkan keterampilan sosial dalam pelajaran IPS pada siswa kelas IV B SDN 03 Nambangan Kidul Kota Madiun Tahun pelajaran 2015/2016? Adapun tujuan dari penelitian ini adalah untuk meningkatkan keterampilan sosial dalam pelajaran IPS dengan menggunakan permainan tradisional congklak pada siswa kelas IV B SDN 03 Nambangan Kidul Kota Madiun Tahun pelajaran 2015/2016.

\section{Metode Penelitian}

Penelitian ini menggunakan Penelitian Tindakan Kelas. Subjek penelitian ini adalah siswa kelas IV B SDN 03 Nambangan Kidul Kota Madiun Tahun pelajaran 2015/2016 yang berjumlah 21 siswa meliputi 8 siswa perempuan dan 13 siswa laki-laki.

Teknik pengumpulan data penelitian ini adalah: 1) Observasi yaitu peneliti menggunakan lembar observasi untuk aktivitas peneliti dan aktivitas siswa. 2) Tes yaitu peneliti menggunakan tes pilihan ganda. 3) Dokumentasi yaitu berupa foto kegiatan.

Analisis data dalam penelitian ini ditempuh melalui cara merefleksikan hasil pengamtan dan hasil belajar selama proses pembelajaran berlangsung sesuai siklus dan tindakan yang dilakukan pada setiap siklus.Dengan kriteria penilaian sebagai berikut

$$
S=\frac{K}{N} \times 100
$$

Keterangan:

$\mathrm{S}=$ nilai yang diharapkan (dicari).

$\mathrm{R}=$ jumlah skor dari item atau soal yang dijawab benar.

$\mathrm{N}=$ skor maksimum dar tes tersebut.

(M. Ngalim Purwanto, 2013: 112)

Indikator kinerja dalam penelitian yaitu peningkatan keterampilan siswa yang diperoleh melalui lembar observasi dengan kriteria baik mencapai $80 \%$ dari jumlah siswa keseluruhan. Serta peningkatan hasil tes evaluasi mata pelajaran IPS dengan keberhasilan melalui lembar evaluasi siswa dengan KKM nilai 70 mencapai $80 \%$ dari jumlah siswa keseluruhan.

\section{Hasil dan Pembahasan}

\section{Hasil Penelitian}

a. Siklus I

Hasil capaian keterampilan sosial dalam pelajaran IPS setelah menggunakan permainan tradisional congklak sebagaimana tercantum pada tabel di bawah ini 
gulawentah: Jurnal Studi Sosial

Volume 1 Nomor 1 Juli 2016, hal 14-23

Avaliable online at http://e-journal.ikippgrimadiun.ac.id/index.php/gulawentah

Tabel 1 Keterampilan Sosial pada Siklus I

\begin{tabular}{lccc}
\hline Kriteria & $\begin{array}{c}\text { Jumlah } \\
\text { Siswa }\end{array}$ & $\begin{array}{c}\text { Persentase(\% } \\
\text { ) }\end{array}$ & $\begin{array}{c}\text { Persentase } \\
\text { Kumulatif(\%) }\end{array}$ \\
\hline Sangat Baik & 3 & 14,2 & 14,2 \\
\hline Baik & 4 & 19,1 & 33,3 \\
\hline Cukup & 8 & 38,1 & 71,4 \\
\hline Kurang & 6 & 28,6 & 100 \\
\hline Sangat kurang & 0 & 0 & 100 \\
\hline Jumlah & 21 & 100 & Rata-rata $=70,4$ \\
\hline
\end{tabular}

Data tabel 1 di atas menunjukkan bahwa keterampilan sosial siswa pada siklus I yaitu dengan rata-rata kelas 70,4 dengan kriteria cukup dengan siswa yang memperoleh kriteria sangat baik dan baik (kriteria penelitian) mencapai 33,3\% dengan jumlah siswa 7 dari 21 siswa. Dan siswa yang memperoleh cukup dan kurang mencapai $66,7 \%$ dengan jumlah siswa 14 siswa dari 21 siswa. Sedangkan hasil tes individu siswa bahwa dapat diperoleh nilai dengan KKM 70 dengan perolehan nilai terendah yaitu 50 dan nilai tertinggi adalah 90. Dapat disimpulkan bahwa hasil tes individu siswa dengan hasil rata-rata yaitu 72,4 dengan kriteria cukup.
Dengan jumlah siswa yang memenuhi kriteria tuntas (KKM yaitu 270$)$ mencapai persentase $66,7 \%$ dengan jumlah 14 siswa dari 21 dan yang memenuhi kriteria tidak tuntas (belum mencapai KKM) mencapai persentase $33,3 \%$ dengan jumlah 7 siswa dari 21 siswa keseluruhan.

b. Siklus 2

Capaian hasil pelaksanakan Siklus II penggunaan permainan tradisional congklak dalam meningkatkan keterampilan sosial ditunjukkan pada tabel di bawah ini

Tabel 2 Keterampilan Sosial pada Siklus II

\begin{tabular}{lccc}
\hline Kriteria & $\begin{array}{c}\text { Jumlah } \\
\text { Siswa }\end{array}$ & $\begin{array}{c}\text { Persentase } \\
(\%)\end{array}$ & $\begin{array}{c}\text { Persentase } \\
\text { Kumulatif }(\%)\end{array}$ \\
\hline Sangat Baik & 5 & 24 & 24 \\
\hline Baik & 12 & 57 & 81 \\
\hline Cukup & 4 & 19 & 100 \\
\hline Kurang & 0 & 0 & 100 \\
\hline Sangat kurang & 0 & 0 & 100 \\
\hline Jumlah & 21 & 100 & Rata-rata $=81,8$ \\
\hline
\end{tabular}

Tabel 2 di atas menggambarkan bahwa hasil observasi keterampilan sosial siswa pada siklus II yaitu rata-rata 81,8 dengan kriteria baik dengan siswa yang memperoleh kriteria sangat baik dan baik (kriteria penelitian) mencapai $81 \%$ dengan jumlah siswa 17 dari 21 siswa. Dan siswa yang memperoleh cukup mencapai $19 \%$ dengan jumlah siswa 4 siswa dari 21 siswa. Sedangkan hasil tes individu siswa diatas bahwa dapat diperoleh nilai dengan KKM 70 dengan perolehan nilai terendah yaitu 60 dan nilai tertinggi adalah 100. Dapat disimpulkan bahwa hasil tes individu siswa dengan hasil rata-rata yaitu 82,4 dengan kriteria baik. Dengan jumlah siswa yang memenuhi kriteria tuntas (KKM yaitu $\geq 70$ ) mencapai persentase $85,7 \%$ dengan jumlah 18 siswa dari 21 siswa, dan siswa yang tidak tuntas (tidak memenuhi KKM) mencapai $14,3 \%$ dengan jumlah 3 siswa dari 21 siswa keseluruhan.

Dalam siklus 2 ini sudah memenuhi kriteria keberhasilan penelitian maka penelitian ini tidak dilanjutkan ke siklus berikutnya. 


\section{Pembahasan}

Berdasarkan hasil observasi dan analisis data terdapat adanya peningkatan mengenai aktivitas siswa (keterampilan sosial) dan hasil belajar siswa dalam pembelajaran menggunakan permainan tradisional congklak pada mata pelajaran IPS pada siswa kelas IV B SDN 03 Nambangan Kidul Kota Madiun dari setiap siklus dari siklus I ke siklus II. Hasil peningkatan aktivitas siswa (keterampilan sosial) dapat dilihat pada tabel di bawah ini

Tabel 3 Peningkatan Keterampilan Sosial

\begin{tabular}{lcccc}
\hline \multirow{2}{*}{ Kriteria } & \multicolumn{2}{c}{ Siklus I } & \multicolumn{2}{c}{ Siklus II } \\
\cline { 2 - 5 } & $\begin{array}{c}\text { Jumlah } \\
\text { Siswa }\end{array}$ & $\begin{array}{c}\text { Persentase } \\
(\%)\end{array}$ & $\begin{array}{c}\text { Jumlah } \\
\text { Siswa }\end{array}$ & $\begin{array}{c}\text { Persentase } \\
(\%)\end{array}$ \\
\hline Sangat Baik & 3 & 14,2 & 5 & 24 \\
\hline Baik & 4 & 19,1 & 12 & 57 \\
\hline Cukup & 8 & 38,1 & 4 & 19 \\
\hline Kurang & 6 & 28,6 & 0 & 0 \\
\hline Sangat Kurang & 0 & 0 & 0 & 0 \\
\hline Jumlah & 21 & 100 & 21 & 100 \\
\hline
\end{tabular}

Dari tabel 3diatas dapat disimpulkan bahwa keterampilan sosial siswa dari siklus I yang memperoleh kriteria penelitian (sangat baik dan baik) mencapai 33,3\% (7 siswa dari 21 siswa) dengan rata-rata ktiteria cukup meningkat pada siklus 2, mencapai kriteria penelitian (sangat baik dan baik) mencapai $81 \%$ (17 siswa dari 21 siswa) dengan rata-rata kriteria baik. Sedangkan untuk hasil evaluasi yang diberikan pada setiap siklus, pada siklus 1 dan siklus 2 perolehan nilai diketahui bahwa nilai siswa melalui tes yang diberikan setiap akhir siklus terjadi peningkatan yaitu pada siklus 1 dengan rata-rata kelas 72,4 dengan persentase 66,7\% dengan jumlah 14 siswa dari 21 siswa yang dinyatakan tuntas (memenuhi KKM). Sedangakan pada siklus 2 yaitu dengan rata-rata kelas 82,4 dengan persentase $85,7 \%$ dengan jumlah 18 siswa dari 21 siswa yang dinyatakan tuntas (memenuhi KKM). Sehingga sudah mencapai kriteria berhasil dalam penelitian ini yaitu mencapai jumlah siswa yang tuntas belajar $\geq$ $80 \%$ dari jumlah seluruh siswa.

Dengan demikian permainan tradisional congklak pada mata pelajaran IPS dapat meningkatkan keterampilan sosial siswa. Melalui permainan tradisional congklak pada mata pelajaran IPS siswa bekerja sama dalam kelompok, saling perhatian dalam kelompok dan perhatian terhadap pembelajaran, berbagi tugas atau soal serta menjaga kebersamaan dalam kelompok. Siswa lebih aktif menjawab ataupun bertanya dan menunjukkan semangat/antusias dalam pembelajaran, siswa mematuhi aturan yang telah disepakati bersama dengan waktu yang disediakan serta meningkatkan komunikasi dan rasa kepemimpinan pada siswa. Sehingga memungkinkan siswa aktif dan adanya interaksi antara siswa dalam proses pembelajaran. Hal ini sejalan dengan yang dikemukakan Sadiman (2014: 78-81) bahwa kelebihan permainan adalah permainan adalah sesuatu yang menyenangkan karena ada unsur kompetisi, adanya partisipasif aktif dari siswa/ interaksi antar siswa, memungkinkan penerapan konsep ataupun peran dalam situasi masyarakat, mengajarkan sistem sosial, membantu meningkatkan kemampuan komunikatif, memahami pendapat orang lain, memimpin diskusi kelompok efektif. Sapriya (2014: 191) bahwa kegiatan partisipasi sosial dapat dilakukan melalui simulasi dan permainan (games) yang merupakan proses pembelajaran atau kegiatan di mana siswa belajar mengenal aturan, berkompetisi. Sapriya (2014: 191) bahwa kegiatan partisipasi sosial dapat dilakukan melalui simulasi dan permainan (games) yang 
merupakan proses pembelajaran atau kegiatan di mana siswa belajar mengenal aturan, berkompetisi, dan sekaligus menjadi pemain yang mungkin pada suatu saat akan menjadi pihak yang menang atau pihak yang kalah. Serta yang dikemukan oleh Mutiah (2010:147-153) bahwa aspek-aspek yang dapat dioptimalkan dalak kegiatan bermain adalah (a) bermain untuk perkembangan kognitif (b) untuk pengembangan sosialemosional (mengembangkan kemampuan mengorganisasi dan meyelesaikan masalah, membantu mengekspresikan, membantu menguasai konflik dan mengenali diri sendiri, serta meningkatkan kompetensi sosial meliputi interaksi sosial, kerja sama, menghemat sumber daya, peduli terhadap orang lain), (c) untuk pengembangan motorik (motorik kasar dan motorik halus), (d) untuk pengembangan bahasa/komunikasi. Cahyani (2014) permainan tradisional Indonesia mengandung nilai-nilai yang sangat berguna dalam kehidupan masyarakat Indonesia yaitu mengandung nilai kejujuran, kerja sama, kepemimpinan, dan sportivitas. Khasanah, dkk (2011) bahwa beragam permainan tradisional mengarahkan anak menjadi kaut secara fisik maupun mental, sosial, dan emosi, tak mudah menyerah, bereksplorasi, bereksperimen, dan menumbuhkan jiwa kepemimpinan. Serta Fad (2014: 25) bahwa dalam permainan tradisional congklak diperlukan kemampuan strategi, kerjasama, wawasan, kepemimpinan, dan ketangkasan.

\section{Kesimpulan}

Dari hasil analisis data dapat disimpulkan bahwa dengan penggunaan permainan tradisional congklak pada mata pelajaran IPS dapat meningkatkan keterampilan sosial siswa kelas IV B SDN 03 Nambangan Kidul Kota Madiun Tahun Pelajaran 2015/2016. Hal demikian dapat dilihat dari rerata hasil belajar yang meningkat dari siklus I sebesar 72,4 menjadi 82,4 pada siklus II.
Disamping itu ketrampilan social siswa juga mengalami kenaikan dari 33,3 \% pada siklus I meningkat menjadi $66,7 \%$ pada siklus II

\section{Daftar Pustaka}

Alma, Buchari, dkk. (2010). Pembelajaran Studi Sosial. Bandung: Alfabeta.

Arie, Vanda. (2015). Hore, Aku Tinggi Cerita Seru Permainan Tradisional. Solo: Tiga Serangkai.

Arikunto, Suharsimi. (2007). Penelitian Tindakan Kelas. Jakarta: PT Bumi Aksara.

Cahyani, Ni Putu Dian. (2014). Permainan Tradisional: Media Pembelajaran di Kelas BIPA. Bali: Asile 2014 Conference..

Goleman, Daniel. (2005). Working with Emotional Inteligence (Kecerdasan Emosi untuk Mencapai Puncak Prestasi). Jakarta: PT Gramedia Pustaka Utama.

Gunawan, Rudy. (2013). Pendidikan IPS Filosofi, Konsep, dan Aplikasi. Bandung: Alfabeta.

Khasanah, Ismatul,dkk. (2011). Permainan Tradisional sebagai Media Stimulasi Aspek Perkembangan Anak Usia Dini. Jurnal Penelitian PAUDIA.

Mutiah, Diana. (2010). Psikologi Bermain Anak Usia Dini. Jakarta: Kencana.

Purwanto, Ngalim. (2013). Prinsip-prinsip dan Teknik Evaluasi Pengajaran. Bandung: PT Remaja Rosdakarya.

Rifai, Moh. (2014). Meningkatkan Prestasi Belajar Siswa dengan Pembelajaran STAD pada Pembelajaran IPS Siswa Kela IV MIN Manisrejo Kota Madiun. Premiere Educandum, Vol.04 No.02: 160.

Sadiman, Arief S. (2014). Media Pendidikan: Pengertian, Pengembangan, dan Pemanfaatannya. Jakarta: Rajawali Pers.

Santrock, John W. (2007). Perkembangan Anak. Jakarta: Erlangga. 
gulawentah: Jurnal Studi Sosial

Volume 1 Nomor 1 Juli 2016, hal 14-23

Avaliable online at http://e-journal.ikippgrimadiun.ac.id/index.php/gulawentah

Sapriya. (2014). Pendidikan IPS. Bandung: PT Remaja Rosdakarya.

Thalib, Syamsul Bachri. (2010). Psikologi Pendidikan Berbasis Analisis Empiris Aplikatif. Jakarta: Kencana Media Group.

Trianto. (2014). Model Pembelajaran Terpadu Konsep, Strategi, dan Implementasinya dalam Kurikulum Tingkat Satuan Pendidikan (KTSP). Jakarta: PT Bumi Aksara.

Undang-Undang Republik Indonesia Nomer 20 Tahun 2003 Tentang Sistem Pendidikan Nasional. (2003). Jakarta: Departemen Pendidikan Nasional.

Widoyoko, Eko Putro. (2011). Evaluasi Program Pembelajaran Panduan Praktis bagi Pendidik dan Calon Pendidik. Yogyakarta: Pustaka Pelajar.

Mujib, Fathul dan Nailur Rahmawati. (2011). Metode Permainan-permainan Edukatif dalam Belajar Bahasa Arab. Jogjakarta: DIVA Press (Anggota IKAPI). 